İleri, M. B. (2021). Accession versus exit: european union's size 1ssue throughout the decades. Aksaray Üniversitesi Sosyal Bilimler Enstitüsü Dergisi, 5(1), 1-20. doi:10.38122/ased.779317

Makale Geçmişi / Article History Alindi (Received): 11/08/2020

Düzeltme alındı (Received in revised form): 18/02/2021 Kabul edildi (Accepted): 19/02/2021

\title{
Accession Versus Exit: European Union's Size Issue Throughout The Decades
}

\author{
M. Bahadır İLER I ${ }^{1}$
}

\begin{abstract}
The European political map has been constantly changing since the World War II. The Czechoslavakia and Yugoslavia dissolved, Germany reunited and the European Union (EU) has been expanding. The original European Economic Community (EEC) has grown from 6 to 27 members and the process has been on-going. Enlargement is a permanent and continuous item on the EU agenda and by far one of the most speculated policies. Enlargement policy aims at preparing the countries concerned to become full members of the EU when they, as well as the EU, are ready. Therefore, EU has provided a well-designed institutional framework for enlargement. Nevertheless, it doesn't necessarily mean that EU enlarges only. Even though United Kingdom's (UK) EU departure represented the sharpest challenge of recent times, the cases of Algeria, Greenland and Saint Barthélémy had shown that withdrawal from the EU and the institutions that preceded it, was not an absolutely new phenomenon. The objective of this article is to depict and to compare the institutional framework and the historical background of the enlargement and withdrawing facts. A discussion of theorization falls outside the scope of this illustrative paper and it is just aimed to provoke thinking.
\end{abstract}

Keywords: European Union, Europe, enlargement, shrinking.

Öz: İkinci Dünya Savaşı'ndan bu yana Avrupa'nın siyasi haritası devamlı değişmektedir. Çekoslavakya ve Yugoslavya dağıllırken, Almanya birleşirken, Avrupa Birliği (AB) devamlı suretle genişlemektedir. 6 üyeyle kurulan Avrupa Ekonomik Topluluğu (AET) 27 üyeli bir topluluğa evrilirken, süreç de devam etmektedir. Genişleme, kalıcı ve sürekli bir unsur olarak her daim Avrupa gündemindedir ve en çok speküle edilen politika alanlarından da biridir. Genişleme politikası, ilgili ülkelerin AB'ye tam üye olmaya hazırlanmaları ve AB'nin de buna hazırlıklı olmasıdır. Bu nedenle, AB genişleme konusunda iyi tasarlanmış bir kurumsal çerçeveye sahiptir. Öte taraftan "AB sadece genişlemektedir" demek de doğru bir önerme değildir. Birleşik Krallık'ın (BK) AB'den ayrılması son zamanların en keskin sınamalarından biri olsa da Cezayir, Grönland ve Saint Barthélémy vakaları, AB'den ve onun selefi kurumlardan çıkış konusunun tamamıyla yeni bir fenomen olmadığını göstermektedir. Bu makalenin amacı, $\mathrm{AB}$ bağlamındaki katılım ve çıkış olgularının kurumsal çerçevelerini ve tarihsel arka planlarını ortaya koyarak bir kıyasa imkân vermektir. Kuramsal tartışmalar, betimleyici bu çalışmanın maksadı dışındadır ve özünde düşünceyi teşvik hedeflenmektedir.

Anahtar Kelimeler: Avrupa Birliği, Avrupa, genişleme, daralma.

\section{Introduction}

The European Union (EU) is one of the world's biggest economies, a major source of foreign direct investment, a leading distributor of humanitarian and financial assistance, and the most prominent norm entrepreneur. In short, EU is a significant global actor and since 1960s it managed to transform that community of six Western European States into a hybrid organization of 27 Member States. Prosperity, stability and security spreaded throughout the continent and enlargement has been

\footnotetext{
${ }^{1}$ M. Bahadır İLERİ, Ankara Üniversitesi Uluslararası İlişkiler Ana Bilim Dalı, mileri@ankara.edu.tr, ORCID: 00000003-2220-5966
} 
widely regarded as the most successful EU foreign policy tool. Nevertheless, the withdrawal of the United Kingdom (UK) from the EU (Brexit) took place and the EU shrank significantly even though it was not the first time in its history. Thus, the EU is such a dynamic entity that has witnessed several rounds of enlargement and at the same time a couple of exits throughout these years.

The accession to the EU has proved to be a key catalyser for progress, since significant changes came out by each enlargement wave. Mediterranean countries, Greece, Spain and Portugal, adopted Western democracy after long periods of authoritarianism. Central and Eastern European States (CEES) converted their socialist regimes into liberal market economies. Malta and Greek Administration of Southern Cyprus (GASC) were attached to the rest of Europe and particularly saved from labeling as 'Mediterranean orphans' (Preston, 1997: 210). The stability or at least "cold peace" has been established in all over the Western Balkans after the tragic events of 1990s. Last but not least, Turkey has put into force enormous political reforms and provided a deep socio-political transformation.

However, EU has not always enlarged, but also shrunk. The withdrawal optionfor EU Member States was accepted for the first time in 2009 with the "Treaty of Lisbon amending the Treaty on European Union and the Treaty establishing the European Community- TFEU (Treaty of Lisbon); and the UK has followed the leaving process outlined there. Nevertheless, it has been always argued that as long as the consent of the other parties is obtained, any soverign state is allowed to withdraw from any international agreement at any time due to the Article 54 of the Vienna Convention on the Law of Treaties, 1969. And taking into consideration that EU is partly an international organisation and partly a supranational organisation, and EU Member States retain full sovereignty in many matters, ad-hoc solutions were always found for the disintegration experiences until the TFEU put into force.

Apperently, despite the vast amount of literature on enlargement issue, there is limited number of studies on withdrawal from the EU. This might be unsurprising; because until the Brexit happened, the withdrawal provision had been largely considered as a marginal case restricted to dependent territories of the Member States, which are geographically far, demographically small, and economically fragile compared to the EU. Taking into account the lack of a comparative study between enlargement and withdrawing issues in European studies, this paper seeks to answer the following questions:

1. How the withdrawal option evoked before the Brexit?

2. Is splitting from the EU easier than accessing to the EU?

3. What are the similar and distinct features of enlargement and exit phenomena?

In order to discuss the above-mentioned questions and to depict the dynamic nature of the EU, this paper is organized rougly as follows: introduction, two sections examining the enlargement and 
departure policies respectively and conclusion. Following the introduction, the first half of the paper (Section 1,2) reviews the enlargement policy and its history, and the second half of the paper (Section 3,4 ) examines the issue of the withdrawal from the Union and its implications. Ultimately, the last part (Section 5) wraps up the topic, processes and concludes the research questions. This study is entirely illustrative to provoke thinking and a discussion of theorization falls outside its scope. And the conceptualisations offered in this study are expected to improve, expand and deepen our understanding of the enlargement and shrinking phenomena in a holistic way.

Before turning to the substance of the analysis in this paper, it is useful to briefly consider a few points of terminology. The term enlargement adresses to the process of admitting new Member States or territories to join the EU; meanwhile, withdrawal from the EU indicates the judicial and political process whereby a Member State or part of its territories become a third party to the EU.

\section{THE EU ENLARGEMENT POLICY AND ITS INSTITUTIONAL FRAMEWORK}

In the field of EU studies, various definitions of enlargement can be found. Schimmelfennig and Sedelmier defines enlargement as "a process of gradual and formal horizontal institutionalization of organizational rules and norms". Here, the term "institutionalization" is used to refer to "the process of which the inter-actions of social actors are patterned normatively". And the term "horizontal" institutionalization applies to the case when "institutions spread beyond the current actors (Member States) and the organization rules and norms become applicable in a wider geographic context". "Organizational rules and norms" are defined as "formal outputs of the EU such as the conclusion of treaties". And finally, the term "gradual" means "a step by step process that begins before and continues after the admission of new members to the Union" (Schimmelfennig \& Sedelmeier, 2002: 503).

$\mathrm{EU}$ is one of the unique cases that so many cultures and languages co-exist, not only without conflicting with each other but also keeping "unity in diversity". And there is a well-designed institutional framework to extend that diversity: Enlargement. To put in other words, there are certain norms and procedures to manage the geographical expansion. For years, the guideline of enlargement have remained almost the same. Article 49 of the TFEU, which is used to be Article 237 of the Treaty of Rome and later became Article $\mathrm{O}$ of the Maastrict Treaty, defines the whole procedure.

The Article 49 of the TFEU ensures that "Any European country, which respects and promotes the fundamental values of the EU, may apply for full membership". The process is officially launched when a European country submits the formal application to the European Council. Very importantly, countries wishing to join the "Club", first need to meet the Copenhagen Criteria ${ }^{2}$ that is composed of

\footnotetext{
${ }^{2}$ It was named after the European Council in Copenhagen/Denmark in 1993 which defined them.
} 
several political and economic criteria, and the administrative and institutional capacity to effectively implement the acquis communitaire (acqui) and the ability to take on the obligations of membership of the applicant country.

Besides that, two additional criteria are also essential to evaluate a country's suitability for EU membership: the country's ability to adopt the obligations of the EU, and vice-versa, the Union's capacity to absorb the candidate country. In addition, "Madrid Criteria" was added at the Madrid Summit held on 15-16 December 1995, and it was required from the candidate states to establish necessary administrative and legal structures to implement the harmozied legislation. All in all, a candidate country faces with six criteria in total, five of which directly concern themselves, and the sixth is exclusive to the Union.

After the application, the Council asks the Commission to give an avis, in which recommendations are presented for further steps. If it is considered that the Applicant State meets the above-mentioned criteria sufficiently, the accession process starts, which basically consists of three distinct stages.

When the conditions are met, the Commission may recommend the recognition of candidate status to the Applicant State and starting the accession negotiations. The negotiations begin once the Council issues a negotiating mandate to the Commission. Acquis, which is composed of 35 different chapters dealing with various policy fields such as agriculture, energy, environment, institutions etc., is negotiated between the EU and the Candidate State. The accession negotiations are not designed to establish a new community, but rather to absorb new-comers into the existing structures. On the contrary to classical negotiations, candidate countries have very little room to maneuver vis-à-vis the EU. Undisputedly, the Candidate State cannot negotiate on the acquis itself, but only when and how to apply it. In sum, every Candidate State has to adopt, implement and enforce the acquis. After the completion of the negotiations on all chapters, the accession treaty is prepared and endorsed by the Council, the Commission and the European Parliament (EP) seperately, and later signed and ratified by all Member States and the Candidate State. Finally, the acceding country becomes a Member State at the date determined in the treaty.

In all these phases of the enlargement, "conditionality" plays crucial role by linking progress from one phase to another. According to this so-called "carrot and stick" approach of conditionality, the process slows down or accelerates depending on a basic concept of "How much a candidate country meets the EU's expectations?".

The Council of the EU (European Council) is the essential platform, where the most critical decisions are taken on enlargement policy. Among the Council, the General Affairs Council (GAC) decides on the official status of an Applicant State, to open and close the formal membership negotiations, and to approve the accession of a Candiate State. The decision-making exclusively relies 
on unanimity of the Member States (European Council, 2019). And the Commission takes the most active role in enlargement policy among rest of the EU institutions. "Enlargement policy puts the Commission in such an exceptionally powerful position that, not only the Candidate States but also the Member States become depended on the information and skills that only the Commission could bring" (Heidbreder, 2011: 8). Within the Commission, a Commissioner is exclusively responsible for the enlargement policy and in this regard, the Directorate-General for Neighborhood and Enlargement Negotiations (DG NEAR) deals with managing the policies that fall into the scope of EU's enlargement strategy. DG NEAR is responsible for monitoring the progress of candidate countries towards the EU (European Commission, 2019). The duties include the preperation of the initial avis, the monitoring of the progress of the candidate country, the conduct of the negotiations, the preparation of the negotiating briefs to the EU, and to present final avis. Finally, according to Article 49 of the TFEU, Parliament's consent is compulsory for any new accession to the EU. Parliament's resolutions also influence the enlargement policy itself (European Parliament, 2017).

\section{THE HISTORY OF THE ENLARGEMENT POLICY}

Enlargement has always been an essential part of European integration and even in the Schumann Declaration of 9 May 1950, the idea of a "united Europe" was set as a goal. This section gives a synopsis of the enlargement history, which means the constant increase of the number of Member States from six to 27. To date, five main enlargement waves have occurred.

Table 1. Enlargement Waves ${ }^{3}$

\begin{tabular}{|l|l|l|}
\hline First (Western) Wave & 01.01 .1973 & UK, Denmark and Ireland \\
\hline Second (Southern) Wave & $\begin{array}{l}01.01 .1981 \text { (First Round) } \\
01.01 .1986 \text { (Second Round) }\end{array}$ & $\begin{array}{l}\text { Greece } \\
\text { Spain and Portugal }\end{array}$ \\
\hline Third (Northern) Wave & 01.01 .1995 & Austria, Finland and Sweden \\
\hline Fourth (Eastern) Wave & 01.05 .2004 (First Round) & $\begin{array}{l}\text { Poland, Hungary, the Czech Republic, } \\
\text { Slovakia, Slovenia, Estonia, Latvia, } \\
\text { Lithuania, Malta and GASC } \\
\text { Bulgaria and Romania }\end{array}$ \\
\hline Fifth Enlargement Wave & 01.01 .2013 & Croatia \\
\hline
\end{tabular}

\footnotetext{
${ }^{3}$ There are several versions of naming and defining the enlargement waves in literature and official documents. In this study, the waves are categorized into four major categories by taking into account the geographical context, the time sequence and the common features of the accession countries. Very importantly, some waves include different rounds and this was justified on two grounds. First, decision-makers had to consider that concessions for the countries in the first round became presecedents for the countries in the second round and the accession norms, rules and procedures were quite similar in each enlergament wave.
} 
The first enlargement process was initiated by the UK's application for European Economic Community (ECC). In 1961, UK's decision to apply for full membership was followed by Ireland, Denmark and Norway as well. On the way to membership the biggest problems arose from UK's insist on preserving its special ties with the ex-colonies, Ireland's undeveloped agricultural economy, Norway's sensitivity on fishery policy and Denmark's Euroscepticism. After the vetoes of 1963 and again in 1967 by French President Charles de Gaulle, four countries were finally allowed to join in 1973. Norway, which spent four fifth of her history under either Danish or Swedish rule chose to maintain its "full independence" and rejected the EU membership by a popular referendum (Bjorklund, 1997: 149). Eventually the UK, Ireland and Denmark were involved in the first enlargement wave. The membership had visible effects on the new Member States. Ireland's agriculture-based economy turned into an industrial economy and permanent peace was achieved in Northern Ireland. The UK had to revise its special ties with the rest of the Commonwealth countries, but her economy performed significantly better than before. Denmark, on one hand did not accept to stay outside of the enlargement process, and on the other hand kept several hesitations regarding the integration issue. Eventually, Denmark obtained four derogations or "opt-outs" from EU cooperation on the Monetary Union (EMU), Common Security and Defence Policy (CSDP), Justice and Home Affairs (JHA) and the European Citizenship.

The second enlargement is considered as one of the hardest enlargement waves. Greece, Spain and Portugal had all in common that they were developing Mediterranean countries trying to consolidate their newly restored democracies. Furthermore, agriculture was the crucial sector for their gross domestic product and their economy was doing bad in general. The Southern Enlargement happened in two distinct phases. First, Greece accessed to the EEC in 1981, which was followed by Spain and Portugal in 1986. Greece, a country from the Eastern Christianity and having several problems with her neighbors, managed to enter the Communities. Therefore, it is not wrong to conclude that this enlargement wave has been regarded as a fundamental transition of the EEC from being solely an economic community into a political one as well. The Commission suggested that "Greece had to commit itself not to block Turkish accession at a later stage" (Butler, 1978: 100) but it was never happened. Regarding Spain and Portugal, even though dictatorships were ended by the end of the 1970s, the sceptism towards their political system was not over. Portugal was the poorest country in the Western Europe and besides her economic backwardness, Spain was also perceived as a big "threat" in agricultural sector for some member states (France and Italy) due to the climatic advantage she enjoyed. Plus, the Spanish fishing fleet at the time was the largest in comparision to the total number of the fishing fleets of the Communities and that was another challenge for some Member States (UK, Ireland and the Netherlands) (Emmert \& Petrovic, 2014: 1369-1371). Consequently, restrictions came into agenda for the new Member States. "Greek accession became 
effective on January 1, 1981, but a general transition period of five years was reserved regarding the free movement of Greek workers and tomatoes to the old Member States" (ibid.). Similarly, Spain and Portugal obtained full freedom of movement only after seven years later than their admission to the Communities in 1986. Furthermore, they were offered only a limited improvement in their access to EU waters, and they were not admitted to the Common Fishery Policy (CFP) until 1996. Despite several political and economic challenges, the second enlargement wave conduced to increasing relations with other regions of the world, including Latin America and North Africa (Viñas, 2000: 79).

The collapse of the Berlin Wall in 1989 triggered a series of dramatic events that eventually ended up with political reunification of the Eastern Germany (German Democratic Republic-GDR) and the Western Germany (Federal Republic of Germany-FRG). Hence, the accession of the GDR to the FRG was managed within the context of joining of the 5 "new Länder" to the the eleven "old Länder". For the first time, a post-communist community was involved in the integration process of the Western Europe (Kühnhardt, 2009: 48).

The third round of EU enlargement (1995) -Finland, Austria and Sweden- occured after the incorporation of the Communities into the EU in $1993 .{ }^{4}$ The northern enlargement was the easiest and the smoothest expansion that the EU had ever experienced and the whole accession negotiations took less than two years. Primarily, this enlargement wave made the EU "richer" with higher democratic standards. Despite their strong political and economic structures, these countries were also transformed by the EU as well. Finland committed more to the European integration, than the other Nordic Member States -Denmark and Sweden- due to the need of enhancing her economic growth and foreign security. As a result, Finland participated both to the Eurozone and EU security missions without reservations (Tiilikainen, 2006: 78). The alcohol monopoly in Sweden became a big problem during the negotiations; hence it was resolved in a way that Sweden had to gradually adopt the EU rules on the transportation of tobacco and alcohol products within the EU (The Swedish Retail Institut, 2019). Austria, which was a member of the European Economic Area (EEA) had already adopted about two-thirds of the acquis. Although Austria submitted three applications for accession to the three European Communities, each of which contained a reservation concerning Austria's neutrality, they met with EU rejection. As a result, Austria subsequently reduced the concept of neutrality to the "military core" (Heinisch, 2001: 269) and finally accepted as a new Member State by the Union.

\footnotetext{
${ }^{4}$ Norway, supposed to be the most integrated non-EU country to the EU, had also considered joining the EU, but the majority of the Norwegians once again rejected EU membership in a popular referendum in 1994, as they did in 1972 as well.
} 
Following the shredding of the Iron Curtain, CEES emerged as new candidates that had "particularly low level of socio-economic development, struggling with specific problems of transformation from a communist society, and political traditions shaped by long periods of authoritarianism and foreign domination" (Schimmelfennig, 1999: 5). The applications of Malta and GASC, the "Mediterranean orphans", were also brought into the same enlargement basket by the EU. Although the vast majority of the Member States were not in favour of accepting a divided country into the Union, Greece's blackmail to veto the whole enlargement process resulted with the inclusion of GASC among that particular enlargement round. Membership negotiations with GASC were concluded without major obstacles due to its better political and economic alignment, except for the banking regulations (Dinan, 2005: 153). And Malta's accession was even easier than the GASC since it was already a very small country without serious political or economic hardcomings. Eventually, it was agreed to carry out the enlargement wave in two phases with Poland, Hungary, the Czech Republic, Estonia, GASC, Latvia, Lithuania, Malta, Slovakia, and Slovenia in 2004, and Bulgaria and Romania in 2007. The number of Member States was almost doubled with an increase from 15 to 25. "Big bang enlargement" brought much more heterogeneity to the Union, stable democracies had emerged, ethnic conflicts had been probably avoided and economic growth had been ensured.

Croatia is the last acceding country, at least to date. Croatia applied for EU membership in 2003 and negotiated her EU membership according to a new method that includes benchmarks for opening and closing policy chapters. Furthermore, Croatia had to accept durable solution with her borders with Slovenia, who blocked Croatia's accession talks in 2008. In addition, Croatia was forced to maintain full cooperation with the International Criminal Tribunal for the former Yugoslavia. In the end, Croatia had managed to enter the Union in 2013, slightly before the rise of the multiple crises (Eurozone crisis, the refugee crisis, Brexit and the rise of anti-systemic political movements across Europe) that EU had to face with.

Appereantly, the EU enlargement policy has been slowed down, but not ended entirely. During the on-going enlargement process towards the Western Balkans, political stability has been largely provided, internal and external security has been improved, economy has been grown, and dialogue channels have been created between conflicting parties. The framework of the Stabilisation and Association process (SAp) encouraged the Western Balkan countries "to tackle the challenges of reforming democratic institutions, promoting trade and economic development, and combating corruption, ethnic violence, poverty and social exclusion" (European Commission, 2019) in order to maintain their EU membership perspective. According to the new enlargement methodology, in addition to the Copenhagen Criteria, additional conditions for membership were set out in the "Stabilisation and Association Process", mostly referring to regional cooperation and good neighbourly relations. 
Even though, Turkey is officially not part of that revised enlargement methodology, Turkey is another candidate country with large population, geographically strategic location, and high potential in economy, security and military-related topics. Turkey has been part of the EU integration since the very beginning and applied to the EEC in 1959, barely two years after the Treaty establishing the European Economic Community. In the end, Ankara Association Agreement (AA) was signed in 1963, which presented an interim step towards the accession. Furthermore, Customs Union was established between Turkey and the EU in 1996, and following a series of socio-political reforms, Turkey-EU accession negotiations started in 2005. In addition, Turkey has been one of the first countries which EU went into further cooperation on various issues including energy, migration, combatting organized crime, counter-terrorism, visa liberalization and up-date of the Customs Union.

To sum up, since its inception in 1957, the EU has grown constantly and several successive enlargement waves took place. Top-down Europeanization and membership perspective to the EU, forced all candidate countries to adopt democratic, socio-economic and security reforms. The original top-down perspective shows "the domestic impact of the EU on candidate/accession countries that have no say in EU decision-making and whose relationship with the EU is asymmetrical" (Börzel, 2019). For all old and new candidate countries, the symbolism of integrating to 'Europe' became as important anchor - and perhaps more important - than any other of the tangible benefits of the EU membership. Moreover, as the EU has grown, the attractions of access and the potential costs of exclusion have become greater.

Roles for each EU institutions have been clearly defined as the EU adapted its institutions and decision-making processes to the future enlargements successfully by introducing clear set of rules. On one hand, candidates have very little room to maneuver versus the EU. On the other hand, "conditionality" is applied to all candidate and potential candidate countries, and accession process was basically defined as "evolutive and inclusive" for all candidates (Martin \& Schwarzinger, 2017: 38).

Enlargement is an effective EU policy that spreads liberal-democratic values, economic growth, social development and political stability. Manifestly, the EU has become more heterogeneous regarding institutional performance, political priorities, social and cultural diversity, and financial abilities. But simultaneously, the EU has been enriched each time by the potential of the acceding states. The TFEU recognizes that all European countries which respect fundamental European values have right to apply for membership. Besides the mentioned European values, geography is an essential condition too. No hesitation was shown to reject the Morocco's membership application in 1987. However, Europe's Eastern borders are highly contested unlike the natural borders at the North, 
South and West of the Europe and it is highly likely that Turkey and the countries in the Western Balkans will be the last accesing countries to the EU.

\section{THE WITHDRAWAL POLICY AND ITS INSTITUTIONAL FRAMEWORK}

The theoritisation of exit policy is relatively new. Schimmelfennig argues it with the term "differentiated disintegration", which means "the selective reduction of a state's level and scope of integration", and which has internal and external dimensions. According to this, "a member state may remain in the EU but exits from specific policies" (internal differentiation) or "it exits from the EU but continues to participate in selected EU policies" (external differentiation) (Schimmelfennig, 2018: 1154).

Until the TFEU the substantive rules regarding the framework of negotiating a country's withdrawal from the EU did not exist. Until 2010, ad-hoc solutions were applied for a number of departures from the EU. The most common solution refers to the fact that, as no any treaty deals with the Member States' borders directly, any Member State was considered as capable of changing her territories unilaterally, for instance by granting authonomy to one of her entities. Then, it becomes the sole responsibility of this entity to decide whether to remain or leave the Union.

Article 50 of the TFEU has been the first legal foundation of the leaving procedure. However, in comparison to accession, withdrawal procedure does not contain clear norms and rules, and it is commonly criticised as 'incomplete, unclear' and even 'cryptic' (Hillion, 2015: 135). In addition, any Member State may exit the Union without the consent of the remaining Member States, while enlargement requires unanimity.

The Article is composed of five main elements. To browse into the content of the article:

$>$ The first paragraph indicates the inition of the withdrawal process: "Any Member State may decide to withdraw from the Union in accordance with its own constitutional requirements".

$>$ The second paragraph adresses to the institutions taking part in the withdrawal process: "A Member State which decides to withdraw shall notify the European Council of its intention. In the light of the guidelines provided by the European Council, the Union shall negotiate and conclude an agreement with that State, setting out the arrangements for its withdrawal, taking account of the framework for its future relationship with the Union. That agreement shall be negotiated in accordance with Article 218 (3) of the Treaty on the Functioning of the European Union. It shall be concluded on behalf of the Union by the Council, acting by a qualified majority, after obtaining the consent of the EP."

The third paragraph shows the time-sequences of the withdrawal or expulsion process: "The Treaties shall cease to apply to the State in question from the date of entry into force of the withdrawal agreement or, failing that, two years after the notification referred to in paragraph 
2, unless the European Council, in agreement with the Member State concerned, unanimously decides to extend this period."

And the last paragraphs cover the further procedures of the withdrawal or re-application:

$>$ "For the purposes of paragraphs 2 and 3, the member of the European Council or of the Council representing the withdrawing Member State shall not participate in the discussions of the European Council or Council or in decisions concerning it. A qualified majority shall be defined in accordance with Article 238 (3)(b) of the Treaty on the Functioning of the European Union."

$>$ "If a State which has withdrawn from the Union asks to rejoin, its request shall be subject to the procedure referred to in Article 49."

In order to by-pass the uncertainty within the EU and in the withdrawing Member State, time provisions are set to prevent the delayed and protracted procedures (Kiss, 2017: 89). If the Exiting State asks for an extension of these time provisions, this can be done for a specified period of time, once unanimity is reached. All the relevant work on strategic, functional, legal and financial issues related to the withdrawal process and the future relationship between the parties is conducted through the negotiations. The Commission initiates the negotiation process by submitting its recommendations to the Council and later holds the negotiations on behalf of the Union (Perakis, 2019: 43). The Council takes the decisions by qualified majority, unlike in the enlargement process. Concluding an agreement between the EU and the Exiting State is not obligatory. If an agreement on the extension of a deadline cannot be reached, the membership status of the withdrawing state automatically ends. Each and every Exiting State is also bound by their own constitutional requierements and the EP has the formal role at the very end of the process. The time point of the withdrawal is decided either by the time mentioned in the withdrawing agreement or two years following the notification of the withdrawal. It is also decided that the exit process shall be ended once the Exiting State revokes its notification, without requiring the consent of the Member States. Last but not least, the duty of sincerity and good faith are the essentials of the whole process.

\section{THE HISTORY OF THE DEPARTURE FROM THE COMMUNITIES/UNION}

As a widely-known generic statement, EU is a sui-generis international organization which is less than a state but more than an international organisation, and therefore it is also complicated to figure out whether the history of departures from the EU falls into a 'state-breaking' or an 'international organisation breaking' case. However, one thing is clear that formally exiting the EU is not a recent phenomenon and three territories have already left the Union even before the Brexit 
took place. Nevertheless, every exit was managed by its own dynamics. Algeria left the Communities after gaining independence from France in 1962. Greenland and Saint Barthélémy changed their status from Outermost Region (OR $)^{5}$ to Overseas Country and Territory (OCT), and consequently these territories fell out of the EU territories, even though their nationals kept their European citizenships. Ultimately, the UK became the first Member State which left the Union. Therefore, it is necessary to focus on each of these departures in order to reach a comprehensive understanding of the exit phenomenon of the EU.

Algeria became the first "territorial loss" of the Union. She was part of the French mainland until its independence in 1962 and therefore, Algeria was effectively a member of the Common Market since 1957. More than a decade long French colonialism, linked the Algeria to the rest of Europe closely, since Algeria formed a juridical part of France directly. Only after two years following the end of the war, France faced the truth that Algeria was no longer part of France or Europe, since an independent state in Africa could not stay as part of the European integration. Ahmed Ben Bella, the first elected president of the newly established country, submitted a request to the Communities to negotiate the future of the bilateral relations on 24 December 1962. Algeria dropped its affiliation with the EEC in 1962, but it became ambigious since Article 227 Paragraph 2 classified Algeria as a beneficiary of some EEC directives (Brown, 2017: 199), such as enjoying the duty-free access of her products into the European markets through France. Following periodical negotiations and ad-hoc agreements, only in 1976 Algeria and EEC signed a Cooperation Agreement, and finally in 2005 they signed an Association Agreement to formalise their relations. In a nutshell, Algeria left the EU according to an EU doctrine which explictly states that "if part of the territory of a Member State would cease to be part of that state because it were to become a new independent state, the Treaties would no longer apply to that territory".

The second exit from the Union happened at the other side of the Atlantic. Since Greenland was part of Denmark and Denmark applied for membership in 1961 and 1967 respectively and finally joined the EEC in 1973, Greenland also became part of the EU, unlike the Faroes which had the option to remain outside. In fact, in a referendum held in Greenland in 1972, slightly more than 70\% of the votes were against the EU membership. Greenland held another membership referendum in 1982, after Greenland received greater autonomy and Home Rule was established on May 1, 1979. As a result, 52 percent of the population (the same ratio of the Brexit) voted to leave the Union, since Greenland's secession bid was foremost about the resistance to the common fishing policy, as the fishing industry made up of almost 90 percent of the whole economy. Eventually, the Greenlandic Autonomous Government requested to withdraw from the EEC, and the Danish Government

\footnotetext{
${ }^{5}$ No matter how far they are from the European continent, the outermost regions are an integral part of the EU, where the acquis is fully applicable in their territories.
} 
requested the Council to amend the Treaties in order to allow the withdrawal. The exit process of the largest island in the World was challenging and until 1985, harsh negotiations were held in the triangle of Nuuk, Copenhagen, and Brussels. Lars Vesterbirk, Greenland's former representative to the EU, defined these negotiations as a surprisingly unpleasant job, since the Member States were not willing to accept that Greenland should or could leave the Union (Politico, 2019). Eventually, an agreement was reached in 1984 and the existing Treaties were then amended, according to the Article 236 of the Treaty establishing the European Economic Community. This had then to be ratified by all Member States and Greenland finally withdrew from the EEC on 1 February 1985. In fact, Greenland's withdrawal was mentioned not as a real secession, but more like a "redefinition of the territory of the Kingdom of Denmark" (Friel, 2004: 420-425). Since then, Greenland turned out an OCT based on the Greenland Treaty.

Saint Barthélémy, the smallest island of the French West Indies, located in the Caribbean region, joined the "Group of EU leavers" in 2012. Apparently, Saint Barthélémy is comparable neither with Greenland in terms of geographical size, nor with UK in terms of economical or demographic aspects, but it was the most recent departure from the EU until the Brexit. The island of Saint-Barthélemy, which was discovered by Christopher Columbus in 1493, became a French territory from 1648 onwards. The volcanic island later annexed to Guadeloupe and became one of its municipalites in 1946. Later, the process of statutory changes resulted with the adoption of a new status as a "French Overseas Territory" in 2007, following a referandum in 2003. As SaintBarthélemy became separate entity, independent of the Guadeloupe, automatically she became an OR after the entry into force of the TFEU. However, Saint-Barthélemy considered that her EU membership was causing commercial disadvantages in her trade with the USA (Saint-Barthélemy's largest trade partner) specifically due to the EU competition law, since the other regional actors such as Puerto Rico and Grenada were not bound with such rules and regulations. In order to satisfy the demand of Saint Barthélémy, not the Article 50, but the Articles 349 and 355 of the TFEU had been triggered, which deal with overseas territories and allow their status-change. As of 1 January 2012 Saint Barthélemy became an OCT, based on the unanimous vote of the European Council on 29 October 2011.

The most recent and the most challenging withdrawing was the case of the UK. Throughout her almost half century long EU membership, the UK has always been regarded as a reluctant Member State, which kept several opt-outs including the EMU and Schengen Agreement. Finally in 2013, the UK's then-Prime Minister David Cameron made a promise of holding a referendum on whether the UK should remain in the EU or leave, with the purpose of overcoming the pressure rising from his own party and the opposition. Cameron won the elections and kept his promise of bringing a 
referandum to the public. Cameron backed the "remain" view, while several other political figures in the country, including the London Mayor Boris Johnson, voiced the "leave" option. At first glance, leave campaign focused on identity politics and the remain campaign focused more on economic aspect.

Finally on 23 June 2016, the referendum question was asked to the voters of the UK: Should the UK remain a member of the EU or leave the EU?

As a result of a $72.2 \%$ turnout, $51.9 \%$ voted in favour of leaving the EU. Northern Ireland and Scotland overwhelmingly preferred to remain, but the England and Wales wanted to leave. Cameron announced his resignation the following day. On 29 March 2017, the UK triggered the Article 50 and notified the Council of her objective to leave the EU.

Michel Barnier was appointed as the Chief Negotiator on 22 May 2017 on behalf of the EU and mandated to coordinate all the procedural and operational works, while David Frost became the UK government's Chief Negotiator. Citizens' rights, the financial issues and the Irish question were the three key negotiating strands. There were four possible scenarios regarding the Brexit process:

- The extension of the transition period.

- Concluding a Withdrawal Agreement

- Leaving the EU with no deal

- Going another referandum

The UK was expected to leave the EU at 11pm on 29 March 2019, however due to failure of reaching a settlelement and the lack of the consent of the British Parliament, the UK asked for three extensions in total througout the negotiation process. On 19 October 2019, the new Brexit deal was lost on amendment in the British Parliament and on 12 December 2019, the Prime Minister (PM) Boris Johnson retained power with a clear majority in the UK General Elections and his commitment to "get Brexit done" by 31 January 2020 was reaffirmed. January became the procedural month of the Brexit since one confirmation followed the other. On 23 January 2020, The Withdrawal Agreement -negotiated by the UK and the EU- became a UK law; having received royal assent, having passed from both Houses of Parliament. The very next day, President of the European Council Charles Michel and the President of the European Commission Ursula von der Leyen signed the Withdrawal Agreement in Brussels, while the UK PM Boris Johnson signed the agreement in London. Ultimately, the EP ratified it on 29 January 2020, The Trade and Cooperation Agreement between the EU and the UK to reshape the relationship between the EU and the UK entered into force on 1 January 2021, and all EU primary and secondary law were ceased to be applicable to the UK.

The Brexit Deal provided a post-Brexit transition period until 31 December 2020, of which UK would be subjected to all EU rules and regulations. Fundamentally, the Deal covered three main issues 
namely citizen rights, financial settlement and the "Irish Backstop". According to this, it was ensured to safeguard the rights to live, work, and study of around 3.6 million European citizens in UK, and one million vice-versa. Regarding the financial settlement, it was agreed to keep the commitments made during the EU membership of the UK. And on the "Irish Question", the parties accepted a plan in which border checks between Northern Ireland and Republic of Ireland were avoided in order to maintain the fragile peace in the region. Under the revised deal, Northern Ireland kept remaining in UK's customs territory, but in practice it was supposed to implement a sort of customs border between the Great Britain and Northern Ireland (UK Government, 2019).

In sum, any of the exits have not happened (yet) in the Continental Europe. It seems a bit difficult to find a common pattern of the exit procedure until the TFEU. Nevertheless it is clear that withdrawing is a complex and complicated issue. The negotiations between the EEC and Algeria conducted intermittently for years, while the negotiations between Greenland-Denmark and the EU took two years. The completion of exit took almost 9 years for Saint Barthélémy and three and a half years for the UK after their referandum results. Not the previous ones but dramatically the "Brexit has exploded the myth of irrevesibility and of irreversible progress towards an ever closer union of the peoples of Europe" (Adam, 2020: 261). On the other hand, it is speculated that Brexit would not be the last case and even possible names for the potential exits of several Member States have been coincided such as Czech-out, Fin-land, Outaly, Maltalavista, Departugal and Swedone.

\section{CONCLUSION}

The European political map has been continiously changing in line with the evolution of the EU, and it becomes either more blue ${ }^{6}$ or less depending the accession of new states or departure of Member States or their respective territories. Therefore, EU is such a complicated and dynamic entity that needs a special focus. Regarding our research questions:

1. Is splitting the EU easier than accessing to the EU?

In theory its not as difficult as entering the Union, since it is just necessary to activate Article 50 of TFEU and follow its procedure of negotiating for two years and then leaving with or without a deal. But in practise; the size of the withdrawing country, the complexity of the level of integration and institutionalising the future relations may turn the process into a more difficult or an easier one.

2. How the withdrawal option evoked before TFEU?

\footnotetext{
${ }^{6}$ The colour as a symbol representing EU.
} 
Apparently, if any territory wanted to withdraw, it had to find a suitable justification. For Algeria it was becoming independent, for Greenland, it was achieving autonomy within Denmark, and for Saint Barthélémy it was redefining her territorial status.

3. What are the similar and distinct features of enlargement and exit phenomena?

\section{Similarities:}

The history of both the enlargement and exit starts by 1960s. The history of enlargement begins with the British, Irish and Danish accession requests in 1961, and the history of departures begins with Algeria in 1962.

Both enlargement and withdrawing processes are officially launched when a country notifies the Council. The outcome of both the accession or withdrawing significantly varies, depending on the "size" of that country.

The withdrawing or accessing State does not involve in the decisions of the Council.

Both accession or withdrawing processes can be hold on or declined at any point of the process. The EP gives its consent by the end of the procedure for both accession or withdrawing. The EP gives its consent by the end of the procedure for both accession or withdrawing Both enlargement and exit cases happen in the first month of a respective year, except for the "bigbang enlargement" in May.

\section{Differences:}

\begin{tabular}{|c|c|}
\hline Accession & Exit \\
\hline No certain time-bounds for the accession. & $\begin{array}{l}\text { The withdrawal takes places automatically two years } \\
\text { after notification, in the absence of an agreement on } \\
\text { time-extension. }\end{array}$ \\
\hline $\begin{array}{l}\text { According to conditionality, accession happens if } \\
\text { the candidate "performs well". }\end{array}$ & A withdrawing state resists more to EU demands. \\
\hline $\begin{array}{l}\text { Accessing countries have very limited negotiating } \\
\text { power than the EU. }\end{array}$ & The negotiations are conducted on an equal basis. \\
\hline $\begin{array}{l}\text { The final destination of every accession talks is } \\
\text { membership. }\end{array}$ & $\begin{array}{l}\text { The final destination of the withdrawal talks is not } \\
\text { unique. }\end{array}$ \\
\hline $\begin{array}{l}\text { The Commission takes very active role throughout } \\
\text { the accession process. }\end{array}$ & $\begin{array}{l}\text { The role of the Commission is limited to submitting } \\
\text { recommendations. }\end{array}$ \\
\hline $\begin{array}{l}\text { The Council of Ministers is the chief actor and } \\
\text { decision-maker on the EU side. And the Chief }\end{array}$ & $\begin{array}{l}\text { The Council of Ministers nominates the "Union } \\
\text { Negotiator". And the Chief Negotiator from the } \\
\text { withdrawing country conducts the negotiations. }\end{array}$ \\
\hline
\end{tabular}




\begin{tabular}{|l|l|}
\hline $\begin{array}{l}\text { Negotiator from the candidate country conducts } \\
\text { the negotiations. }\end{array}$ & \\
\hline $\begin{array}{l}\text { The Council unanimously decides the accession of } \\
\text { a new Member State to the EU. }\end{array}$ & $\begin{array}{l}\text { The Council decides the withdrawing of an existing } \\
\text { Member State by qualified majority. }\end{array}$ \\
\hline Enlargement usually happens in groups. & Exit happens in individual cases. \\
\hline $\begin{array}{l}\text { Integratation has been an objective since the very } \\
\text { begining and there is well-designed rules and } \\
\text { procedures for enlargement. }\end{array}$ & $\begin{array}{l}\text { Disintegration could only be institutionalised by } 2009 \\
\text { and the rules and procedures are not as advanced as in } \\
\text { enlargement policy. }\end{array}$ \\
\hline $\begin{array}{l}\text { It is largely considered that enlargement is } \\
\text { beneficial both for the accessing country and the } \\
\text { Union. }\end{array}$ & $\begin{array}{l}\text { It is largely considered that withdrawing of a Member } \\
\text { State is costly both for the exiting country and the } \\
\text { Union. }\end{array}$ \\
\hline $\begin{array}{l}\text { Public opinion plays an important role in the end, } \\
\text { by approving the Accession Treaty. }\end{array}$ & $\begin{array}{l}\text { Public opinion plays an important role at the very } \\
\text { beginning, by triggering the withdrawing process. }\end{array}$ \\
\hline
\end{tabular}

The EU perceives enlargement as part of its raison d'être. Currently, there are a group of candidate and potential candidate countries and their accession is expected to take place only after the applicants demonstrate their ability to overcome the complex multi-criteria process, and the Union is also willing to accept new members. ${ }^{7}$ In short, the question for the EU is no longer whether to enlarge but how to manage enlargement, because the EU considers that premature accession is bad for all parties (Cecchini, Jones \& Lorentzen, 2001: 166). Highly likely, Europe will integrate further; however disintegration is not an unexpected scenario either. Algeria is a specimen due to its particular nature, but both Greenland and Saint Barthélémy cases were clear examples of EU's positive discrimination by letting them to allow holding the benefits of the EU without assuming the membership obligations. Therefore, not these "unorthodox" withdrawings, but Brexit might unleash a contagion effect among the Member States or their special territories to revise their membership conditions in the future. To conclude, this paper is written to stimulate further thinking on the sophisticated nature of the EU accession and withdrawing processes, and also to provoke additional research about the ambigious and speculative aspects of these policy circumstances.

\footnotetext{
${ }^{7}$ Even though Turkey's EU accession negotiations had effectively come to a standstill, accession process is the backbone of Turkey-EU relations. Turkey is neither a neighbour nor a strategic partner of the EU, but rather is a candidate country which seeeks to revitalize the accession process, to start Customs Union modernization process, to ensure visa liberalization for Turkish citizens to the Schengen area and a better cooperation in the management of irregular migration.
} 


\section{REFERENCES:}

Adam, Rudolf G. Brexit: Causes and Consequences, Cham: Springer, 2020.

Bjorklund, Tor. "Old and New Patterns: The "No" Majority in the 1972 and 1994 EC/EU Referandums in Norway." Acta Sociologica 40, no 2 (1997): 143-159.

Börzel, A. Tanja. “The Transformative Power of Europe,” Freien Universität, Access: 01 February 2019, http://userpage.fu-berlin.de/kfgeu/kfgwp/wpseries/WorkingPaperKFG_11.pdf.

Brown, Megan. "Drawing Algeria into Europe: Shifting French Policy and the Treaty of Rome (1951-1964).” Modern \& Contemporary France 25, no 2 (2017): 191-208.

Butler, Frederick William. Greece and the European Economic Community, Monterey: Naval Postgraduate School, 1978.

Cecchini, Paolo, Erik Jones \& Jochen Lorentzen. “Europe and the Concept of Enlargement.” Survival 43, no 1 (2001): 155-166.

Dinan, Desmond. Ever Closer Union: An Introduction to European Integration. Basingstoke: Palgrave Macmillan, 2005.

Emmert, Frank and Petrovic, Siniša. "The Past, Present, and Future of EU Enlargement.” Fordham International Law Journal 37 no 5 (2014): 1349-1419.

European Commission. Building the Future Together. Access: 14 January 2019 http://ec.europa.eu/enlargement/pdf/financial_assistance/cards/publications/brochure_en.pdf . European Commission. European Neighborhood Policy and Enlargement Negotiations. Access: 14 December 2019. http://ec.europa.eu/enlargement/about/directorate-general/index_en.htm.

European Commission. Trade Help Desk. Access: 21 April 2019. https://trade.ec.europa.eu/tradehelp/overseas-countries-and-territories.

European Council. EU Enlargement. Access: 01 December 2019. http://www.consilium.europa.eu/en/policies/enlargement/.

European Parliament. The Enlargement of the Union. Access: 10 October 2017. http://www.europarl.europa.eu/atyourservice/en/displayFtu.html?ftuId=FTU_6.5.1.html.

Friel, Raymond J. "Providing a Constitutional Framework For Withdrawal From The EU: Article 59 Of The Draft European Constitution." International \& Comparative Law Quarterly 53, no 2 (2004): 407-428. 
Touch on Brussels. New York: Palgrave Macmillan, 2011.

Heinisch, Reinhard. "Austria: Confronting Controversy." in The European Union and the Member States. Cooperation, Coordination, and Compromise, Eds. Eleanor E. Zeff and Ellen B. Pirro. 267-284. Boulder: Lynne Riemer Publisher: 2001.

Hillion, Christopher. "Accession and Withdrawal in the Law of the European Union" in the Oxford Handbook of European Union Law, eds. Anthony Arnull \& Damian Chalmers, 126-152. Oxford: Oxford University Press, 2015.

Kiss, Lilla-Nóra. “Certain Issues Of The Withdrawal Of A Member State.” A Public Law Aspect 70 no 3 (2017): 86-97.

Kühnhardt, Ludger. "The Fall of the Berlin Wall and European Integration," Konrad Adenaur $\begin{array}{lllll}\text { Stiftung, } & \text { Access: } & 02 & \text { February }\end{array}$ http://www.kas.de/upload/Publikationen/Panorama/2009/1/kuehnhardt.pdf.

Lass-Lennecke, Katja and Annika Werner. "Policies, Institutions and Time: How the European Commission Managed the Temporal Challenge of Eastern Enlargement.” Journal of European Public Policy 16, no 2 (2009): 270-285. 2009

Martin, Sajdik and Michael Schwarzinger. European Union Enlargement: Background, Developments, Facts, New York: Routledge, 2017.

Perakis, Manolis. Exiting the European Union: Legal Procedure, Dimensions and Implications. Newcastle: Cambridge Scholars Publishing, 2019.

Politico. Greenland's Exit Warning to Britain. Access: 10 October 2019, https://www.politico.eu/article/greenland-exit-warning-to-britain-brexit-eu-referendumeurope-vote-news-denmark/.

Preston, Chris. The Enlargement and Integration of the European Union: Issues and Strategies. New York: Routledge, 1997.

Schimmelfennig, Frank. "The Double Puzzle of EU Enlargement: Liberal Norms, Rhetorical Action, and the Decision to Expand to the East", ARENA Working Papers no. 99/15, Oslo.

Schimmelfennig, Frank and Ulrich Sedelmeier. "Theorizing EU Enlargement: Research Focus, Hypotheses and the State of Research.” Journal of European Public Policy 9, no 4 (2002): 500528. 
The Swedish Retail Institut. Swedish Alcohol Policy. Access: 24 November 2019. https://brewersofeurope.org/uploads/mycms-

files/documents/archives/hui_2009_swedish_alcohol_policy_study.pdf.

Tiilikainen, Teija. "Finland - An EU Member with a Small State Identity." Journal of European Integration 28 no 1 (2006): 73-87.

UK Government. New Withdrawal Agreement and Political Declaration. Access: 01 December 2019. https://www.gov.uk/government/publications/new-withdrawal-agreement-and-politicaldeclaration.

Viñas, Angel. "The Enlargement of the European Union: Opportunities and Concerns for Spain." Mediterranean Politics 5, no 2 (2000): 76-92. 